\title{
Characterization of $(1,3)$ - $\beta$-glucan synthase in Candida albicans: microsomal assay from the yeast or mycelial morphological forms and a permeabilized whole-cell assay
}

\author{
David J. Frost, Kim Brandt, John Capobianco and Robert Goldman
}

Author for correspondence: David J. Frost. Tel: +1 708937 5322. Fax: +1 7089381021.

Anti-Infective Research Department 47M, Building AP9A, Abbott Laboratories, Abbott Park, IL 60064-3500, USA

\begin{abstract}
A systematic evaluation of the in vitro $(1,3)$ - $\beta$-glucan synthase assay parameters was performed using microsomes prepared from Candida albicans from either yeast or mycelial phase cells. Enzyme activities of both yeast and mycelial phase microsomes depended on the presence of guanosine-5'-0-(3thiophosphate) and either bovine serum albumin or a detergent [W-1 (polyoxyethylene ether detergent) or Brij-35 (polyoxyethylene ether, 23 lauryl ether)]. Brij-35 was included in standard assays as it was compatible with the permeabilized whole-cell assay. Microsomes derived from both the yeast and mycelial phases generally yielded similar glucan synthase activities under a range of different assay conditions. Brij-35 significantly stabilized the enzyme, yielding a half-life of $5.6 \mathrm{~d}$ at $4{ }^{\circ} \mathrm{C}$, compared with $0.9 \mathrm{~d}$ without detergent. The addition of detergent during mechanical breakage of yeast cells dramatically improved glucan synthase stability and activity. Enzyme catalysis was linear for at least $75 \mathrm{~min}$ with $100 \mu \mathrm{g}$ protein from microsomes of yeast cells grown to mid-exponential phase, with an apparent $K_{m}$ for UDP-glucose of $1.1 \mathrm{mM}$. The $\mathrm{pH}$ and temperature optima were 7.75 and $30^{\circ} \mathrm{C}$, respectively. Glucan synthase activity was highest in cells derived from early mid-exponential phase and declined to a basal level by stationary phase. A permeabilization-based in situ assay for glucan synthase was developed. Cells were permeabilized with $\mathbf{2} \%$ (v/v) solution of toluene/methanol (1:1) and assayed for glucan synthase activity using standard reaction mixtures. Reactions were linear for $\mathbf{3 0}$ min and were inhibited by known inhibitors of glucan synthesis. This study represents the first characterization of glucan synthase using yeast and mycelial phase microsomes and adaptation of a permeabilized system using a single $C$. albicans strain with standardized assay conditions.
\end{abstract}

Keywords: Candida albicans, (1,3)- $\beta$-glucan synthase, permeabilized whole-cell assay

\section{INTRODUCTION}

Fungal infections from Candida albicans and other fungi pose a serious risk to immunocompromised individuals such as human immunodeficiency virus (HIV) patients and cancer patients rendered neutropenic by chemotherapy. Currently available fungicidal drugs are only marginaliy effective and new compounds are actively being sought (St Georgiev, 1988). The fungal cell wall serves as a protective barrier and is essential for viability

Abbreviations: UDP-glucose, uridine diphosphate glucose; BSA, bovine serum albumin; GTP $\gamma 5$, guanosine-5'-O-(3-thiophosphate); Brij-35, polyoxyethylene ether, 23 lauryl ether; $W-1$, polyoxyethylene ether detergent. in a hypotonic environment. A major component of the $C$. albicans cell wall is $(1,3)-\beta$-glucan, and since the enzyme that biosynthesizes this polymer is not present in higher eukaryotes, it represents an ideal target for the development of antifungal agents.

$(1,3)-\beta$-Glucan synthase (EC 2.4.1.34) is a plasmamembrane-localized enzyme that transfers glucose from UDP-glucose to a growing polymer of $(1,3)$ - $\beta$-glucan. GTP is an important activator of cell-free glucan synthase preparations and probably plays a critical role in the regulation of cell-wall biosynthesis and cell growth (Kang \& Cabib, 1986; Shematek \& Cabib, 1980; Szaniszlo et al., 1985). In addition to GTP, many other effectors must be 
added to microsomal glucan synthase assays to maximize in vitro catalytic activity. BSA activates the enzyme from Saccharomyces cerevisiae (Shematek et al., 1980), C. albicans (Orlean, 1982) and from other fungal sources (RuizHerrera, 1992). BSA could be substituted with $\beta$ lactoglobulin in S. cerevisiae (Frost et al., 1992). Recently, the detergent $\mathrm{W}-1$ was reported to activate the C.albicans enzyme (Tang \& Parr, 1991). NaF and ATP have also been added to in vitro assays as activators (Shematek et al., 1980; Orlean \& Ward, 1983). Direct comparisons of activating factors for glucan synthases in C. albicans have not been conducted for the yeast and mycelial forms. Both forms are important in pathogenicity (Odds, 1988). Assay conditions as well as sensitivity to drugs targeted against glucan biosynthesis could vary depending on the morphological form of the organism.

The substrate for $(1,3)-\beta$-glucan synthase, UDP-glucose, does not diffuse through intact membranes; thus the plasma membrane must be permeabilized to develop a whole-cell-based assay. Organic solvents have been used to permeabilize fungal cells (Ram et al., 1983; Sentandreu et al., 1975). In this paper we have modified the organic solvent permeabilization procedure to obtain active glucan synthase preparations which incorporate added UDP-glucose into $(1,3)$ - $\beta$-glucan product. Assay conditions for glucan synthase utilizing cell-free extracts from both the yeast and mycelial forms as well as a whole-cell in situ assay system using a single $C$. albicans strain (CCH 442) are described. Structure-activity relationships of glucan synthesis inhibitors derived from these assay systems can then be compared to antifungal activity levels in vitro and efficacy in vivo in mouse pathogenicity models.

\section{METHODS}

C. albicans cultures. The A TCC strains were obtained from the American Type Culture Collection, Rockville, MD, USA. All other strains were obtained as clinical isolates from Cook County Hospital $(\mathrm{CCH})$ and are standard cultures at Abbott Laboratories.

Culture conditions. Yeast cells (C. albicans $\mathrm{CCH} 442$ ) were inoculated into $375 \mathrm{ml}$ YEPD medium [1\%(w/v) yeast extract (Difco), $2 \%(\mathrm{w} / \mathrm{v})$ peptone (Difco), and $2 \%(\mathrm{w} / \mathrm{v})$ glucose] and shaken at $30^{\circ} \mathrm{C}$ for $24 \mathrm{~h}$. Cells were then transferred to $15 \mathrm{l}$ YEPD medium and grown to the mid-exponential phase $\left(\mathrm{OD}_{600}\right.$ 2.5). The mycelial form was obtained according to the method described by Lee et al. (1975) with some modifications. Cells were grown in Lee's medium at $25^{\circ} \mathrm{C}$ for $48 \mathrm{~h}$ on a rotary shaker at 200 r.p.m. A $16 \mathrm{ml}$ portion of the preculture was used to inoculate $166 \mathrm{ml}$ prewarmed $\left(37^{\circ} \mathrm{C}\right)$ medium. The cells were incubated as above at $37^{\circ} \mathrm{C}$ for $6-8 \mathrm{~h}$. Microscopic examination of the cultures revealed that over $98 \%$ of the cells contained at least a germ tube by $4 \mathrm{~h}$ and mycelium by $6.5 \mathrm{~h}$. Incubations longer than $8 \mathrm{~h}$ gave increasingly higher proportions of y'east present in the culture. Both yeast and mycelia were harvested by centrifugation at $3000 \mathrm{~g}$ for $10 \mathrm{~min}$.

Isolation of microsomal membranes. Cells were disrupted with a Bead-Beater, $340 \mathrm{ml}$ vessel size (Biospec Products). Cell paste $(70-90 \mathrm{~g}$ wet wt) and $160 \mathrm{~g}$ glass beads $(0.5 \mathrm{~mm})$ were suspended in $250 \mathrm{mM}$ sucrose, $3 \mathrm{mM}$ EDTA, $3 \mathrm{mM}$ EGTA, $4 \mathrm{mM}$ DTT, $20 \mathrm{mM} \beta$-mercaptoethanol, $25 \mu \mathrm{M}$ GTP and $70 \mathrm{mM}$ Tris/ $\mathrm{HCl}$, pH 8.0 (homogenization buffer). The Bead-Beater was operated five times with $30 \mathrm{~s}$ bursts and 5 min cooling intervals. Crude extracts were recovered and beads were washed with an equal volume of $1 \mathrm{mM}$ EDTA, $1 \mathrm{mM}$ EGTA, $4 \mathrm{mM}$ DTT, $25 \mu \mathrm{M}$ GTP and $50 \mathrm{mM}$ Tris/HCl, pH 8.0 (washing buffer). Fractions were combined and centrifuged at $1000 \mathrm{~g}$ for $10 \mathrm{~min}$ to remove cell debris. The suspension was then centrifuged at $23000 \mathrm{~g}$ for $10 \mathrm{~min}$. To recover microsomal membranes the resultant supernatant was recentrifuged at $80000 \mathrm{~g}$ for $1 \mathrm{~h}$ at $4{ }^{\circ} \mathrm{C}$. Microsomal membranes were then resuspended in $1.0 \mathrm{mM}$ EDTA, $1.0 \mathrm{mM}$ DTT, $33 \%(\mathrm{v} / \mathrm{v})$ glycerol and $50 \mathrm{mM}$ Tris $/ \mathrm{HCl}, \mathrm{pH} 7 \cdot 5$ (storage buffer) for storage at $-80^{\circ} \mathrm{C}$. Protein was assayed by Coomassie blue dye-binding with $\mathrm{BSA}$ as standard (Bradford, 1976).

(1,3)- $\beta$-Glucan synthase assay. Unless otherwise stated, the standard assays were performed in a final volume of $100 \mu \mathrm{l}$ $2.0 \mathrm{mM}$ UDP- $\left[{ }^{14} \mathrm{C}\right]$ glucose $\left(0.625 \mathrm{mCi} \mathrm{mmol}^{-1}\right), 1 \mathrm{mM}$ EDTA, $8 \%$ (v/v) glycerol, $20 \mu \mathrm{M} \mathrm{GTP} \gamma \mathrm{S}, 0.5 \%$ Brij-35, $80 \mathrm{mM}$ Tris/ $\mathrm{HCl}, \mathrm{pH} 7 \cdot 75$, and enzyme $(100 \mu \mathrm{g}$ protein). Assay mixtures were incubated for $30 \mathrm{~min}$ at $30^{\circ} \mathrm{C}$ and stopped by addition of $100 \mu \mathrm{l}(\mathrm{w} / \mathrm{v}) 10 \%$ trichloroacetic acid. Samples were transferred to a 96-well MilliBlot-D (Millipore) containing a Type G-10 glass-fibre filter (Inotech). Each well was washed three times with $300 \mu \mathrm{l}$ distilled deionized water. The filters were removed, air-dried and counted on a direct beta counter (Matrix-9600, Packard Instruments). Units of activity (U) are defined as nmol glucose incorporated into trichloroacetic acidinsoluble glucan per min.

Growth phase study and strain comparison. A $5 \mathrm{ml}$ overnight culture of each strain was used to inoculate $200 \mathrm{ml}$ batches of YEPD which were shaken at $30^{\circ} \mathrm{C}$. At defined intervals (Fig. 1) cells were harvested by centrifugation. Cells were disrupted with glass beads using a Mini-bead Beater (Biospec Products). Paste $(0.6 \mathrm{~g}$ wet $\mathrm{wt})$ was added to $1.85 \mathrm{~g}$ chilled glass beads $(0.5 \mathrm{~mm})$ and then suspended in homogenization buffer. The Bead-Beater was operated six times with $20 \mathrm{~s}$ bursts and $2 \mathrm{~min}$ cooling intervals. Crude extracts were recovered, the beads were washed with an equal volume of washing buffer and combined fractions were centrifuged at $1000 \mathrm{~g}$ for $10 \mathrm{~min}$ to remove cell debris. Supernatants were then centrifuged at $40000 \mathrm{~g}$ for $45 \mathrm{~min}$. Resultant peliets (particulate samples) were resuspended in storage buffer.

Permeabilized whole-cell glucan synthase assay. The in situ assay for $(1,3)-\beta$-D-glucan synthesis was based on previous work of Ram et al. (1983). Cells were grown to an $\mathrm{OD}_{600}$ of 2.0 in YEPD $(300 \mathrm{ml})$. The cells were centrifuged at $8000 \mathrm{~g}$ for $5 \mathrm{~min}$, resuspended in $4 \mathrm{ml}$ storage buffer and recentrifuged at $3000 \mathrm{~g}$ for $5 \mathrm{~min}$ at room temperature. The pellets were resuspended in $4 \mathrm{ml}$ storage buffer and permeabilized with $2 \%(\mathrm{v} / \mathrm{v})$ toluene/methanol $(1: 1)$ at $22^{\circ} \mathrm{C}$ for $5 \mathrm{~min}$. A nonpermeabilized control was also conducted. The samples were washed twice with storage buffer at $4{ }^{\circ} \mathrm{C}$ and resuspended to $6 \mathrm{ml}$ with storage buffer $\left(4^{\circ} \mathrm{C}\right)$. Glucan synthase assays were performed as described above except that $58 \mu \mathrm{l}$ permeabilized cells $\left(5 \times 10^{7}\right.$ c.f.u., $3-4 \mathrm{mg}$ dry wt) were used in the assay. Nonpermeabilized cells were used as baseline controls. Assay mixtures were incubated for $30 \mathrm{~min}$ at $30^{\circ} \mathrm{C}$ and stopped by addition of $100 \mu \mathrm{l} \mathrm{10 \% (w/v)} \mathrm{trichloroacetic} \mathrm{acid.} \mathrm{Precipitates}$ were placed on GF/F glass-fibre filters (Whatman) and washed successively with $3 \times 5 \mathrm{ml}$ cold $5 \%$ (w/v) trichloroacetic acid and cold $95 \%(\mathrm{v} / \mathrm{v})$ ethanol $(1 \times 5 \mathrm{ml})$. The radioactivity was determined with a liquid scintillation spectrometer. All data were expressed as nmol glucose incorporated per mg dry cells. To determine dry weight, $58 \mu \mathrm{l}$ cells were diluted in $1 \mathrm{ml}$ of water and the cells were then trapped on GF/F filters and dried in a microwave oven at high setting with six $40 \mathrm{~s}$ bursts (Koliander \& Hampel, 1989). 
Table 1. Activity of microsomal glucan synthase fractions derived from yeast and mycelia (CCH 442)

\begin{tabular}{|c|c|c|c|c|c|c|c|c|c|}
\hline \multicolumn{8}{|c|}{ Assay conditions* } & \multirow{2}{*}{\multicolumn{2}{|c|}{$\begin{array}{c}\text { Relative activity } \\
(\%) \dagger\end{array}$}} \\
\hline \multirow[t]{2}{*}{ GTP } & \multirow[t]{2}{*}{ Brij-35 } & \multicolumn{2}{|c|}{ W-1 (\%) } & \multirow[t]{2}{*}{ BSA } & \multirow[t]{2}{*}{ ATP } & \multicolumn{2}{|c|}{$\mathrm{NaF}(\mathrm{mM})$} & & \\
\hline & & 0.025 & 0.50 & & & 10 & 100 & & \\
\hline- & - & - & - & - & - & - & - & 0 & 0 \\
\hline+ & - & - & - & - & - & - & - & $1 \cdot 0$ & $5 \cdot 6$ \\
\hline+ & + & - & - & - & - & - & - & $100 \cdot 0$ & $100 \cdot 0$ \\
\hline+ & - & + & - & - & - & - & - & $4 \cdot 5$ & $54 \cdot 2$ \\
\hline+ & - & - & + & - & - & - & - & $42 \cdot 2$ & $52 \cdot 4$ \\
\hline+ & - & - & - & + & - & - & - & $69 \cdot 2$ & $47 \cdot 9$ \\
\hline+ & - & - & - & + & - & + & - & $76 \cdot 5$ & $48 \cdot 3$ \\
\hline+ & - & - & - & + & - & - & + & $61 \cdot 6$ & $60 \cdot 0$ \\
\hline- & - & - & - & + & + & - & - & $38 \cdot 0$ & $10 \cdot 8$ \\
\hline
\end{tabular}

* Effector concentrations added were $20 \mu \mathrm{M} \mathrm{GTP} \gamma \mathrm{S}, 0.5 \%$ Brij-35, $0.8 \% \mathrm{BSA}$ and $5 \mathrm{mM}$ ATP. Products were washed on $2.5 \mathrm{~cm}$ Whatman GF/A glass-fibre filters.

† Maximal specific activities were 2.89 and $2.86 \mathrm{nmol} \mathrm{min}^{-1}\left(\mathrm{mg}\right.$ protein) ${ }^{-1}$ for the yeast and mycelial samples, respectively.

Product characterization. The glucan synthase reaction mixtures which were labelled with UDP-[ $\left.{ }^{14} \mathrm{C}\right]$ glucose $(250 \mu]$ reaction volume) were heat-terminated and mixed with 5 vols distilled deionized water. Samples were centrifuged at $15000 \mathrm{~g}$ for $15 \mathrm{~min}$ at $4{ }^{\circ} \mathrm{C}$ and pellets were washed with distilled deionized water. Pellets were resuspended in either (1) $\alpha$ amylase ( $1 \mathrm{mg} \mathrm{ml}^{-1}$ ) (Sigma) in $50 \mathrm{mM}$ Tris/ $\mathrm{HCl}, \mathrm{pH} 7 \cdot 5$, (2) Zymolyase $100 \mathrm{~T}\left(80 \mu \mathrm{g} \mathrm{ml}^{-1}\right.$ ) (ICN Biochemicals) in $50 \mathrm{mM}$ MES/ NaOH, pH 6.5 and $1 \mathrm{mM}$ DTT, (3) pronase $\left(50 \mu \mathrm{g} \mathrm{ml} \mathrm{m}^{-1}\right)$ (Calbiochem) in $50 \mathrm{mM}$ Tris $/ \mathrm{HCl}, \mathrm{pH} 7 \cdot 5$, or (4) laminarinase,

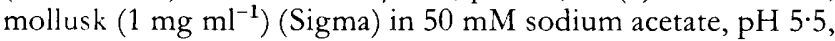
to a final volume of $200 \mu \mathrm{l}$. Mixtures were incubated for $20 \mathrm{~h}$ and the samples were washed and counted on glass-fibre filters as described for the standard enzyme assays.

Following reaction with UDP- $\left[{ }^{14} \mathrm{C}\right]$ glucose, permeabilized cells (200 $300 \mathrm{mg}$ wet wt) were washed and resuspended in $0.3 \mathrm{ml}$ $20 \mathrm{mM}$ sodium phosphate, $\mathrm{pH} 7 \cdot 0,6 \mathrm{mM}$ sodium chloride buffer (PBS). The cells were disrupted by vortex mixing in a glass tube with $0.5 \mathrm{~mm}$ glass beads $\left(4^{\circ} \mathrm{C}\right)$. Lysed fractions were centrifuged and the resulting pellets were dissolved in $2 \%$ SDS in $10 \mathrm{mM}$ Tris $/ \mathrm{HCl}, \mathrm{pH} 7 \cdot 0$, and heated at $100^{\circ} \mathrm{C}$ for $5 \mathrm{~min}$ to solubilize mannoproteins. The SDS-insoluble material was incubated with (1) $\alpha$-amylase $\left(1 \mathrm{mg} \mathrm{ml}^{-1}\right)$ in PBS, (2) proteinase $\mathrm{K}\left(1 \mathrm{mg} \mathrm{ml}^{-1}\right)$ in PBS, or (3) Zymolyase-100T (100 units) in sodium acetate, $\mathrm{pH} 5.5$ in a final volume of $500 \mu \mathrm{l}$ at $30^{\circ} \mathrm{C}$ for 17- $24 \mathrm{~h}$. Samples were centrifuged and ${ }^{14} \mathrm{C}$ radioactivity remaining in each fraction was determined.

Reproducibility of results. All in vitro experiments were repeated at least twice with different batches of microsomal membranes. Mean values with standard deviations are given in each table and figure as representative values from experiments.

\section{RESULTS}

\section{Activity of different strains}

Several C. albicans strains were evaluated for glucan synthase activities. Strain ATCC 10231 had the lowest activity $\left[7 \cdot 9 \pm 0 \cdot 65 \mathrm{U}(\mathrm{mg} \text { protein })^{-1}, n=4\right]$ while strain
ATCC 38247 had the highest activity $[35.6 \pm 0.91 \mathrm{U}(\mathrm{mg}$ protein $)^{-1}, n=4$ ]. Except for strain ATCC 38247, the other strains were either clinical isolates or ones typically used in mouse pathogenicity models. Strain CCH 442 was chosen for all subsequent experiments because it was a clinical isolate that exhibited high glucan synthase activities [19.0 $\left.\pm 0.64 \mathrm{U}(\mathrm{mg} \text { protein })^{-1}, n=4\right]$. Moreover, $\mathrm{CCH} 442$ easily transforms from the yeast to the mycelial morphology and is amenable for use in permeabilized assays.

\section{Effects of assay conditions}

Selected assay mixtures previously developed for $(1,3)-\beta$ glucan synthase from various fungi were evaluated using both the yeast and mycelial forms of $C$. albicans (Table 1). As expected, glucan synthase activity was stimulated by either GTP or ATP in both morphological forms (Orlean, 1982). However, activation by GTP required an additional factor, either BSA or a detergent. BSA $(0.8 \%)$ is added typically to assays with $S$. cerevisiae (Shematek $e$ t al., 1980 ) and C. albicans (Orlean, 1982) glucan synthase, while the detergents Brij-35 (0.5\%) and W-1 $(0.025 \%)$ have stimulated activities from $S$. cerevisiae (Frost et al., 1992) and C. albicans (Tang \& Parr, 1991), respectively. Brij-35 was superior to $\mathrm{W}-1$ in activating $\mathrm{CCH} 442$ glucan synthase $[2.89 \mathrm{U} \text { (mg protein })^{-1}$ versus $1.22 \mathrm{U}$ (mg protein $)^{-1}$. Although $\mathrm{NaF}$ has been cited as a glucan synthase activator in fungi (Orlean \& Ward, 1993; Larriba et al., 1981; Ruiz-Herrera, 1992), NaF gave minimal stimulation compared to the BSA/GTP treatment. Overall, microsomes isolated from either the mycelial or yeast morphological form yielded similar activities. However, one exception was the response to treatment with GTP $/ 0.025 \% \mathrm{~W}-1$ and with the ATP/BSA. Mycelial glucan synthase was activated at a lower concentration of 
Table 2. Effect of $\mathrm{NaF}$ on glucan synthase activities in microsomal membranes derived from the yeast and mycelial forms of $\mathrm{CCH} 442$

\begin{tabular}{|c|c|c|c|c|c|c|}
\hline \multirow{4}{*}{ GTP } & & & \multicolumn{4}{|c|}{ Specific activity $\left[\mathrm{nmol} \mathrm{min}^{-1}\left(\mathrm{mg}\right.\right.$ protein $\left.\left.{ }^{-1}\right)\right] \dagger$} \\
\hline & \multirow{2}{*}{\multicolumn{2}{|c|}{$\begin{array}{c}\begin{array}{c}\text { Assay } \\
\text { conditions* }\end{array} \\
\mathrm{NaF}(\mathrm{mM})\end{array}$}} & \multirow{2}{*}{\multicolumn{2}{|c|}{ No Brij in assay }} & \multirow{2}{*}{\multicolumn{2}{|c|}{ Brij present in assay }} \\
\hline & & & & & & \\
\hline & 10 & 100 & Yeast & Mycelium & Yeast & Mycelium \\
\hline-- & - & - & 0 & 0 & $0 \cdot 33 \pm 0 \cdot 02$ & $0 \cdot 25 \pm 0 \cdot 01$ \\
\hline- & + & - & 0 & 0 & $0.36 \pm 0 \cdot 02$ & $0 \cdot 30 \pm 0 \cdot 02$ \\
\hline- & - & + & 0 & 0 & $0.43 \pm 0.01$ & $0 \cdot 50 \pm 0 \cdot 04$ \\
\hline+ & - & - & $0 \cdot 03 \pm 0 \cdot 01 \ddagger$ & $0 \cdot 16 \pm 0 \cdot 01$ & $2 \cdot 93 \pm 0 \cdot 23$ & $2 \cdot 62 \pm 0 \cdot 08$ \\
\hline+ & + & - & $0.05 \pm 0.01$ & $0.17 \pm 0.01$ & $2 \cdot 80 \pm 0 \cdot 20$ & $2 \cdot 72 \pm 0 \cdot 32$ \\
\hline+ & - & + & $0 \cdot 12 \pm 0 \cdot 02$ & $0 \cdot 25 \pm 0 \cdot 01$ & $3 \cdot 40 \pm 0 \cdot 16$ & $3 \cdot 45 \pm 0 \cdot 13$ \\
\hline- & AMF $\ddagger$ & & $\overline{0}$ & 0 & 0 & 0 \\
\hline
\end{tabular}

*'The final effector concentrations used in the assay were $20 \mu \mathrm{M} \mathrm{CrTP} \gamma \mathrm{S}$ and $0.5 \% \mathrm{Brij}-35$.

† Means $\pm \mathrm{sD}, n=4$.

$\ddagger$ AMF consists of $50 \mu \mathrm{M} \mathrm{AlCl}_{3}, 5 \mathrm{mM} \mathrm{MgCl}_{2}$ and $20 \mathrm{mM} \mathrm{NaF}$.

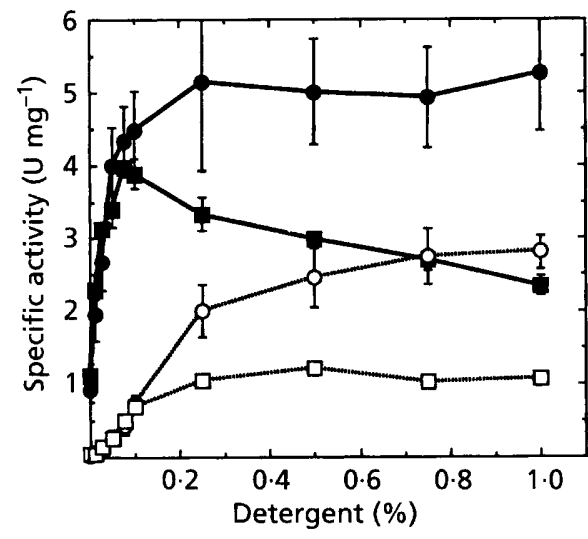

Fig. 1. Effects of Brij-35 and $\mathrm{W}-1$ on $\mathrm{CCH} 442$ microsomal glucan synthase assays. Yeast microsomal membranes were assayed with Brij-35 (O) or W-1 $(\square)$. Microsomes were isolated from cells broken in the presence of $0.5 \%$ Brij-35 and assayed with either Brij-35 (O) or W-1 (目). Error bars represent SD, $n=4$.

W-1 and with the ATP/BSA treatment activity was only $23 \%$ of the GTP/BSA control. The combination of Brij35 and GTP was then used routinely for assays since it provided maximum activities and is compatible to the permeabilized whole-cell assay (see below).

Since $\mathrm{NaF}$ gave only a minor stimulation in our assays, we investigated the possibility that Brij-35 was interfering or substituting the action of $\mathrm{NaF}$. Perhaps either $\mathrm{NaF}$ or Brij-35 could inhibit deleterious enzymes or stimulate directly the glucan synthase complex. Even without Brij35 or GTP, NaF still provided minimal activation (Table 2 ). Therefore, we examined the possibility of a new role for fluoride in the activation of glucan synthase in fungi.
Fluoride is a potent activator of the heterotrimeric Gproteins (Gilman, 1987; Sternweis \& Gilman, 1982). Since the type of GTP-binding protein that interacts with glucan synthesis is unknown, we hypothesized that a $G$ protein could be involved. Fluoride interacts with aluminium to form an $\mathrm{AlF}_{4}^{-}$complex which mimics the $\gamma$ phosphate of GTP when GDP is bound to the $\mathrm{G}_{\alpha}$ subunit, thus activating the protein (Bigay et al., 1987). However, in the absence and presence of $50 \mu \mathrm{M} \mathrm{AlCl}_{3}$ the response was the same (data not shown). Furthermore, addition of AMF $\left(50 \mu \mathrm{M} \mathrm{AlCl}, 5 \mathrm{mM} \mathrm{MgCl}_{2}\right.$ and $\left.20 \mathrm{mM} \mathrm{NaF}\right)$, a standard activation mixture of many $\mathrm{G}$-proteins (Kahn, 1991), totally inactivated the enzyme (Table 2). Inhibition from AMF was due to the presence of $\mathrm{Mg}^{2+}$ since $5 \mathrm{mM}$ $\mathrm{Mg}^{2+}$ alone inhibited glucan synthase activity (data not shown).

Brij-35 greatly stimulated activity with at least a twofold increase in activity relative to $\mathrm{W}-1$ with maximal activities obtained at levels of $0.5 \%$ (Fig. 1). Since Brij-35 strongly activated glucan synthase in the in vitro assay, its addition during bead breakage was examined. Indeed, the specific activity of microsomal membranes with Brij-35 during breakage rose to $5.0 \mathrm{U} \mathrm{mg}^{-1}$ (with $0.5 \%$ Brij present in the assay). Only $0 \cdot 25 \%$ Brij-35 was required in the assay with detergent-isolated microsomes rather than $0.5 \%$. In addition, W-1 inhibited enzyme activity of Brij-isolated microsomes when $\mathrm{W}-1$ levels were greater than $0.06 \%$ in the assay. Inhibition by $\mathrm{W}-1$ is probably due to additive effects of the two detergents since assay mixtures contain carry-over from the cell homogenates.

\section{Characterization of yeast glucan synthase}

Glucan synthase properties vary widely among different fungi (Ruiz-Herrera, 1992) and glucan synthase of $C$. albicans has not been characterized completely. Enzyme 
Table 3. Summary of properties of glucan synthase in microsomal membranes derived from the yeast form of $\mathrm{CCH} 442$ with or without Brij-35 during cell breakage

\begin{tabular}{|c|c|c|}
\hline Property & $\begin{array}{c}\text { Brij } \\
\text { absent }\end{array}$ & $\begin{array}{c}\text { Brij } \\
\text { present }\end{array}$ \\
\hline Optimum pH & $7 \cdot 75$ & $7 \cdot 75$ \\
\hline Optimum temperature $\left({ }^{\circ} \mathrm{C}\right)$ & 30 & 30 \\
\hline Lincarity with time (min) & 90 & 105 \\
\hline Linearity with protein $(\mu \mathrm{g})$ & 110 & 175 \\
\hline \multicolumn{3}{|l|}{ Half-life } \\
\hline \multicolumn{3}{|l|}{ With Brij during preincubation } \\
\hline $4^{\circ} \mathrm{C}(\mathrm{d})$ & $5 \cdot 6$ & $12 \cdot 1$ \\
\hline $30{ }^{\circ} \mathrm{C}(\mathrm{h})$ & $15 \cdot 9$ & $18 \cdot 4$ \\
\hline \multicolumn{3}{|l|}{ Without Brij during preincubation } \\
\hline $4{ }^{\circ} \mathrm{C}(\mathrm{d})$ & $0 \cdot 92$ & $5 \cdot 5$ \\
\hline $30{ }^{\circ} \mathrm{C}(\mathrm{h})$ & $0 \cdot 5$ & $11 \cdot 8$ \\
\hline$K_{\mathrm{ma}, \boldsymbol{y}}(\mathrm{mM})$ & $1 \cdot 1$ & $0 \cdot 9$ \\
\hline 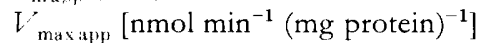 & $4 \cdot 1$ & $12 \cdot 5$ \\
\hline \multicolumn{3}{|l|}{ Product sensitivity: } \\
\hline$x$-Amylase (\% degraded $)$ & $<1$ & $<1$ \\
\hline Protease (\% degraded) & $<1$ & $<2$ \\
\hline \multicolumn{3}{|l|}{1,3 - $\beta$-Glucanase } \\
\hline Zymolyase ( $\%$ degraded) & $>87$ & $>80$ \\
\hline Laminarinase ( $\%$ degraded $)$ & $>99$ & $>99$ \\
\hline
\end{tabular}

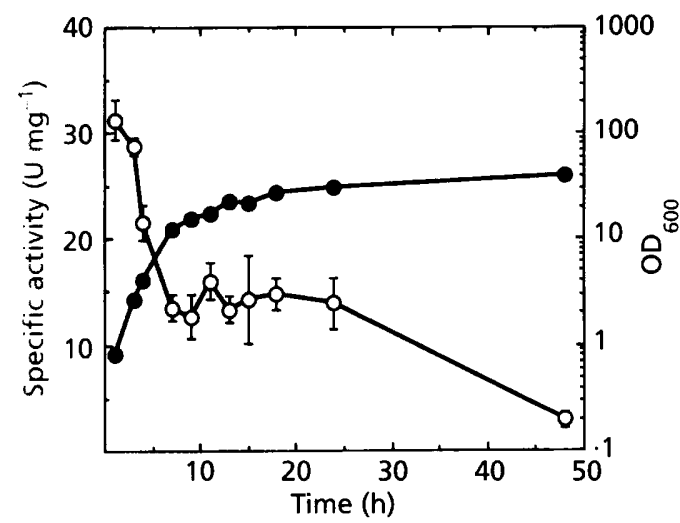

Fig. 2. Effect of growth phase on glucan synthase activities of $\mathrm{CCH}$ 442. Yeast cells were harvested at each time point indicated and microsomal membranes were isolated and assayed as described in Methods. Error bars represent SD, $n=4$. $\mathrm{O}$. Specific activity;, $\mathrm{OD}_{600}$.

characteristics of $C$. albicans in this study are summarized in Table 3. Assays conducted using Brij-35 gave temperature and $K_{\mathrm{mapp}}$ values that were comparable with those reported previously for C. albicans (Orlean, 1982). The half-life of glucan synthase was extended over 6- and 31 -fold at $4^{\circ}$ and $30^{\circ} \mathrm{C}$, respectively with $\mathrm{Brij}-35$ in the buffer used for preincubation of microsomal membranes. A similar response was also reported when the enzyme

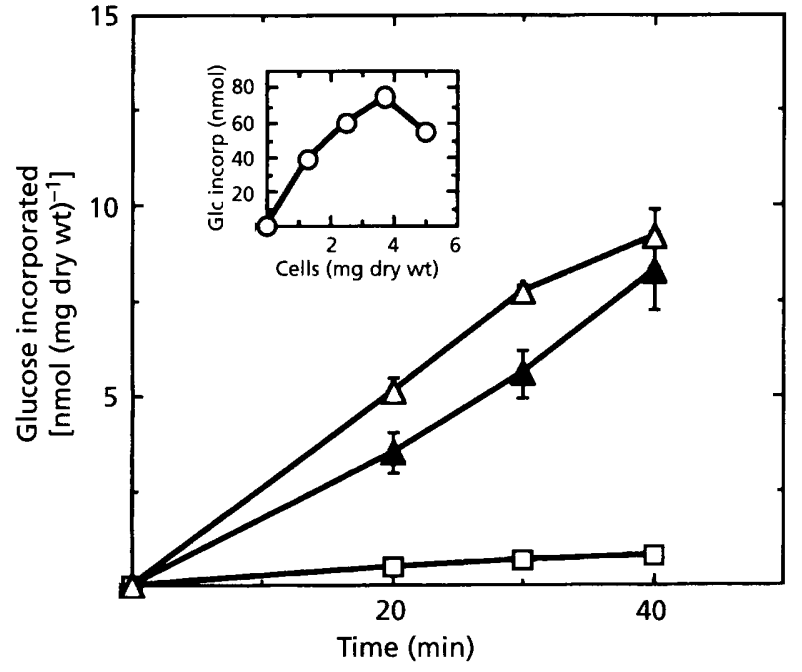

Fig. 3. Permeabilized whole-cell assays of $\mathrm{CCH} 442$ glucan synthase. The main figure shows the incorporation of substrate into product over time using different permeabilized treatments $[\square$, no treatment; $\Delta, 4 \%$ toluene/ethanol (1:1); $\triangle$, $4 \%$ toluene/methanol $(1: 1)]$. The inset shows product formation with the $4 \%$ toluene/methanol (1:1) treatment with increasing amount of cells. Error bars represent SD, $n=3$.

was extracted with W-1 (Tang \& Parr, 1991). However, the addition of Brij-35 during the breakage of cells further extended the half-life. The enzyme was stable for more than $5 \mathrm{~d}$ without additional detergent and $12 \mathrm{~d}$ when $0.5 \%$ Brij-35 was added during stability studies $\left(4^{\circ} \mathrm{C}\right)$. Most of the other glucan synthase characteristics of Brij35 breakage cells were similar to those without detergent during breakage.

\section{Growth phase}

Glucan synthase activities were highest during the early exponential phase of growth of strain $\mathrm{CCH} 442$ and decreased by 10 -fold as growth progressed towards the stationary phase (Fig. 2). Thus, cells are typically during mid-exponential phase so that adequate cell mass and moderate specific activities are obtained. Moreover, we always obtained the highest glucan synthase activities when cells were grown in small shake flasks rather than large-scale fermenters ( $15 \mathrm{l}$ or greater). This could be due to differences in the fermentation conditions since the geometry of the vessels is different. In addition, cell breakage is conducted with different bead-beaters which may alter enzyme activity.

\section{Development of a permeabilized whole-cell assay}

Incorporation of UDP-glucose into product was linear for $30 \mathrm{~min}$ in each treatment (Fig. 3). Toluene/methanol $(\mathrm{T} / \mathrm{M})$ permeabilized cells had the highest incorporation of radioactivity compared to toluene/ethanol treatment. Product formation was roughly linear for $4 \mathrm{mg}$ (dry wt) 


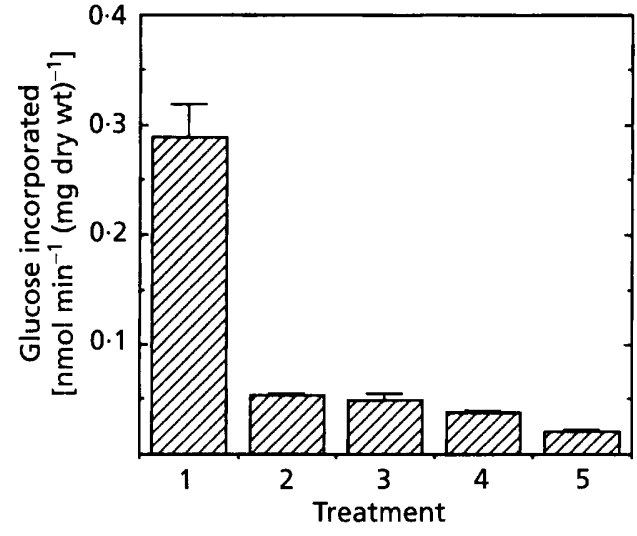

Fig. 4. Effect of different activators on the permeabilized glucan synthase assay ( $\mathrm{CCH} 442)$. The amount of glucose incorporated into product was measured using the $4 \%$ toluene/methanol $(1: 1)$ permeabilized treatment (see Methods). Error bars represent sD, $n=3$. Treatments 1-4 involved permeabilized cells whereas treatment 5 involved nonpermeabilized cells. 1, + Brij + GTP; 2, - Brij + GTP; 3, + Brij - GTP; 4, - Brij - GTP; 5, - Brij + GTP.

of cells (Fig. 3, insert). The permeabilized assay required the presence of Brij-35 and GTP with maximal activation when both activators were present (Fig. 4). Combinations of BSA and GTP did not activate the enzyme (data not shown). A product analysis showed that over $80 \%$ of the added UDP- $\left[{ }^{14} \mathrm{C}\right]$ glucose was incorporated into the SDSinsoluble pellet. This fraction was digested by Zymolyase $(>87 \%)$ and was resistant to either $\alpha$-amylase or proteinase $\mathrm{K}$, thus indicating that the majority of product is $(1,3)-\beta$-glucan.

\section{Effects of inhibitors}

Papulacandin B, cilofungin and echinocandin B each inhibited glucan biosynthesis (Table 4 ). The $\mathrm{IC}_{50}$ values of the glucan synthesis assay in situ were slightly higher than the glucan synthase assay in vitro. This response has been frequently observed using a range of compounds comparing the assays in vitro and in situ (data not shown).

\section{DISCUSSION}

Several different assay conditions have been published for an in vitro $(1,3)-\beta$-glucan synthase reaction in fungi. Only one report of glucan synthase activities has appeared using similar assay conditions in the mycelial and yeast phases of $C$. albicans but a permeabilized system has not been reported (Orlean, 1982). In order to evaluate antifungal agents we needed a uniform assay system that could be used not only with isolated membranes, but also with a whole-cell system. A systematic evaluation of the assay parameters was therefore conducted with $C$. albicans strain $\mathrm{CCH} 442$ and a permeabilized whole-cell assay was developed. Further characterization of the enzyme led to the development of a stable enzyme preparation that achieved optimal activities.

GTP is a common activator of glucan synthase but assay reactions also required either BSA or a detergent (Table 1). The combination of Brij-35 and GTP was most effective for several reasons. BSA can bind drugs and obscure potential leads during screening efforts of antifungal agents. Furthermore, BSA could not be used in the permeabilized system and finally addition of the extra protein to assays can clog the glass-fibre filters and increase the background counts. Mechanism of action is unknown for either BSA or Brij-35, but they may act in a similar manner. BSA may function by sequestering free fatty acids or other endogenous inhibitors lysed during mechanical breakage (Ko et al., 1994). BSA could also slow down proteolysis and detergents could inhibit proteases. Several detergents have been found to activate fungal glucan synthase (Beauvais et al., 1993; Frost et al., 1992; Quigley et al., 1988; San-Blas \& San-Blas, 1982; Tang \& Parr, 1991). Detergents could alter enzyme conformation or membrane fluidity, or act by permeabilizing the membrane to enable better accessibility of substrate and effectors.

Addition of detergent during cell breakage further increased the specific activity and stability of the enzyme while not affecting other enzyme characteristics (Table 3 ). The addition of detergent during breakage is quite important since specific activities of $C$. albicans glucan synthase preparations prepared in the absence of detergent

Table 4. $I C_{50}$ values for inhibitors of glucan synthesis in yeast, mycelial, and permeabilized cell assays ( $\mathrm{CCH} 442)$

Assays were conducted as described in Methods. MIC values of $C$. albicans $\mathrm{CCH} 442$ were 3.0, 3.0 and $1.5 \mu \mathrm{g} \mathrm{ml}^{-1}$ using the microtitre dilution method for papulacand $\mathrm{n} \mathrm{B}$, cilofungin and echinocandin $\mathrm{B}$, respectively.

\begin{tabular}{|lccc|}
\hline Assay condition & \multicolumn{3}{c|}{ IC $_{\mathbf{5 0}}\left(\boldsymbol{\mu} \mathrm{g} \mathrm{m}^{\mathbf{- 1}}\right)$} \\
& $\begin{array}{c}\text { Papulacandin } \\
\text { B Cilofungin }\end{array}$ & $\begin{array}{c}\text { Echinocandin } \\
\text { B }\end{array}$ \\
\hline Yeast microsomes & 4 & 30 & 7 \\
Mycelial microsomes & 4 & 52 & 9 \\
Permeabilized yeast cells & 15 & 75 & 18 \\
\hline
\end{tabular}


can be low ('Taft et al., 1988; Schmatz et al., 1990). Although W-1 has been reported to solubilize glucan synthase from $C$. albicans membranes, we could not solubilize the enzyme from the microsomal membranes using either W-1 or Brij-35 (data not shown). However, Brij- 35 improved the stability and activity of the enzyme in a similar manner to that reported with W-1 treated membranes (Tang \& Parr, 1991).

$\mathrm{NaF}$ is an important activator for many fungi, with the $\mathrm{F}^{-}$ ion acting as the active component (Ruiz-Herrera, 1992). Yet $\mathrm{NaF}$ treatment provided only minimal activation in our assays and Brij-35 did not substitute its action (Table 2). Several mechanisms have been proposed for the action of $\mathrm{NaF}$. Among these $\mathrm{F}^{-}$could protect an endogenous activator distinct from GTP, inactivate phosphatases, stimulate directly the enzyme or inhibit endogenous inhibitors (Orlean \& Ward, 1983; Ruiz-Herrera, 1992). We examined the possibility that $\mathrm{F}^{-}$was acting by a totally different mechanism, that is, through activation of a $G$ protein involved in glucan biosynthesis. Although a GTP-binding protein is involved in glucan synthesis, the type of GTP-binding protein is unknown (Kang \& Cabib, 1986). It has not been determined whether the GTP-binding protein of glucan synthase is a $G$-protein (heterotrimeric protein), a small GTP-binding protein (Ras-like) or another type. Additions of $\mathrm{Al}^{3+}$ with $\mathrm{NaF}$ did not affect glucan synthase activity. Aluminium forms a complex with $\mathrm{F}^{-}$that mimics the $\gamma$-phosphate of GTP when GDP is bound to the $G_{\alpha}$ subunit and activates the protein (Bigay et al., 1987). These data suggest that a classical G-protein is not present in the $\mathrm{CCH} 442$ glucan synthase complex. The mechanisms proposed previously best fit the activation role of $\mathrm{NaF}$ in fungal glucan synthases (Ruiz-Herrera, 1992).

After screening large numbers of $C$. albicans strains the polvene-resistant strain, ATCC 38247, exhibited the highest specific activity for glucan synthase. This strain accumulates methylsterols rather than ergosterol and its membrane is more rigid than that of the wild-type strain (Lees et al., 1989). Membrane fluidity could be an important mechanism of enzyme regulation. Accordingly, chit in synthase activities were higher in polyene-resistant strains and with normal strains when treated with azoles (Pesti et al., 1981; Georgopapadakou, 1992). The alterations in membrane fluidity were suggested to play a central role. The broad range of activity levels amongst different strains could also explain variable responses to activators reported in the literature (Ruiz-Herrera, 1992). Strain CCH 442 was chosen for our experiments because it is a clinical isolate containing high glucan synthase activities, it easily transforms from the yeast to the mycelial morphology and it is amendable for use in permeabilized assays.

C. albicans is a dimorphic fungus and specific morphological forms may play unique roles in pathogenesis (Odds, 1988). Glucan synthase activities from microsomal membranes derived from either mycelial or yeast morphological forms were similar under a wide range of assay conditions except that lower levels of $\mathrm{W}-1$ detergent activated the mycelial form of the enzyme. Furthermore, the mycelial glucan synthase was only marginally responsive to activation by BSA and ATP. These results could suggest that multiple forms of the enzyme are present. Chitin synthase has at least three forms and each one exhibits a differential response to various effectors and drugs (McCullough, 1992; Cabib et al., 1989). One could also envisage specialized forms of glucan synthase which would be required by either the yeast and mycelial forms for both spatial and temporal localizations. Repair functions of the cell wall and specialized interactions with certain polymers such as chitin during septation could also require specialized forms of glucan synthase exhibiting unique regulatory properties.

Cell-wall biosynthetic enzymes are most frequently isolated from yeast cells grown to mid-exponential phase. Chitin synthase from $C$. albicans exhibited its highest activity during active budding and then declined during the stationary phase (Barrett-Bee et al., 1982). Orlean (1982) compared the activities of glucan synthase during the first $4 \mathrm{~h}$ of growth after inoculation with both yeast and mycelia and found that activities rose during early exponential growth. We extended the yeast growth curve and found that activities were highest during the early exponential phase. This was followed by a plateau and subsequent decrease during the stationary phase. Glucan synthase levels therefore followed the expected pattern for cell-wall biosynthesis since cell-wall generation is highest during budding. Low levels of activity may only be required for basal repair or turnover of glucan.

The plasma membrane is a major barrier for many drugs. Certain compounds may be specific and potent inhibitors of glucan synthase assays yet be devoid of antifungal activity. We developed a permeabilized whole-cell assay for glucan synthase to address the permeability issue. In our assay, the toluene/methanol effectively permeabilized the membrane and the incorporation of UDP-glucose to glucan was linear for $30 \mathrm{~min}$. This assay also required GTP and Brij-35. BSA did not activate the enzyme since its large size probably prohibited permeation through the membrane.

Both classes of glucan synthesis inhibitors, the glucolipids (papulacandin B) and lipopeptides (echinocandin B and cilofungin), inhibited the assays in vitro and in situ. The $\mathrm{IC}_{50}$ values were close to the MIC values for papulacandin $\mathrm{B}$ and echinocandin $\mathrm{B}$ but higher for cilofungin. It should be noted that these compounds are inhibitors of glucan synthesis and may not interact directly with the glucan synthase catalytic subunit. Their precise mode of action has yet to be determined (Ruiz-Herrera, 1992).

\section{Conclusions}

In summary, $\beta$-(1,3)-glucan synthesis in fungi is a major pharmaceutical target. The assays described in this paper allow for comparison of compounds inhibiting glucan synthesis. Comparisons can then be extended to antifungal activity in vitro and efficacy in mouse pathogenicity models in vivo. In addition, the detailed characterization of glucan 
synthase should facilitate further purification of the enzyme and determination of its enzymological properties.

\section{REFERENCES}

Barrett-Bee, K. J., Lees, J. \& Henderson, W. (1982). Variation in the activities of enzymes associated with cell wall metabolism during a growth cycle of Candida albicans. FEMS Microbiol Lett 15, 275-278.

Beauvais, A., Drake, R., Ng, K., Diaquin, M. \& Latge, J. P. (1993). Characterization of the $1,3-\beta$-glucan synthase of Aspergilius fumigatus. J Gen Microbiol 139, 3071-3078.

Bigay, J., Deterre, P., Pfister, C. \& Chabre, M. (1987). Fluoride complexes of aluminium or beryllium act on G-proteins as reversibly bound analogues of the $\gamma$ phosphate of GTP. EMBO J 6 , 2907-2913.

Bradford, M. M. (1976). A rapid and sensitive method for the quantification of microgram quantities of protein utilizing the principle of protein-dye binding. Anal Biochem 72, 248-254.

Cabib, E., Silverman, S. J., Sburlati, A. \& Slater, M. L. (1989). Chitin synthesis in yeast (Saccharomyces cerevisiae). In Biochemistry of Cell Walls and Membranes in Fungi, pp. 31-41. Edited by P. J. Kuhn, A. P. J. Trinci, M. J. Jung, M. W. Goosey \& L. G. Copping. Berlin: Springer-Verlag.

Frost, D. J., Drake, R. R. \& Wasserman, B. P. (1992). (1,3)- $\beta$-Glucan synthase from Saccharomyces cerevisiae: In vitro activation by $\beta$ lactoglobulin or Brij-35, and photoaffinity labeling of enriched microsomal fractions with 5-azido-UDP-Glc and 8-azido-GTP. Curr Microbiol 24, 295-300.

Georgopapadakou, N. H. (1992). Chitin synthase as a chemotherapeutic target. In Emerging Targets in Antibacterial and Antifungal Chemotherapy, pp. 476-494. Edited by J. Sutcliffe \& N. H. Georgopapadakou. New York: Chapman and Hall.

Gilman, A. G. (1987). G proteins: Transducers of receptorgenerated signals. Annu Rev Biochem 56, 615-649.

Kahn, R. A. (1991). Fluoride is not an activator of the smaller (20-25 kDa) G'TP-binding proteins. J Biol Chem 266, 15595-15597.

Kang, M. S. \& Cabib, E. (1986). Regulation of fungal cell wall growth: A guanine nucleotide-binding, proteinaceous component required for activity of (1-3)- $\beta$-D-glucan synthase. Proc Natl Acad Sci US A 83, 5808-5812.

Ko, Y.-T., Frost, D. J., Ho, C.-T., Ludescher, R. D. \& Wasserman, B. P. (1994). Inhibition of yeast $(1,3)-\beta$-glucan synthase by phospholipase $\mathrm{A}_{2}$ and its reaction products. Biochim Biopbys Acta (in press).

Koliander, A. W. \& Hampel, W. A. (1989). Rapid determination of ergosterol in yeast cells. Anal Cbimica Acta 225, 129-136.

Larriba, G., Morales, M. \& Ruiz-Herrera, J. (1981). Biosynthesis of $\beta$ glucan microfibrils by cell-free extracts from Saccharomyces cerevisiae. $J$ Gen Microbiol 124, 375-383.

Lee, K. L., Buckley, H. R. \& Campbell, C. C. (1975). An amino acid liquid synthetic medium for the development of mycelial and yeast forms of Candida albicans. Sabouraudia 13, 148-153.

Lees, N. D., Kleinhans, F. W., Broughton, M. C., Pennington, D. E., Ricker, V. A. \& Bard, M. (1989). Membrane fluidity alterations in a cytochrome P-450-deficient mutant of $C$. albicans. Steroids 53, 567-568.

McCullough, J. E. (1992). Importance of chitin synthesis for fungal growth and as a target for antifungal agents. In New Approaches for
Antifungal Drugs, pp. 32-45. Edited by P. B. Fernandes. Boston: Birkhauser.

Odds, F. C. (1988). Morphogenesis in Candida, with special reference to $C$. albicans. In Candida and Candidosis, pp. 42-59. London: Bailliere Tindall.

Orlean, P. A. B. (1982). (1,3)- $\beta$-D-Glucan synthase from budding and filamentous cultures of the dimorphic fungus Candida albicans. Eur J Biochem 127, 397-403.

Orlean, P. A. B. \& Ward, S. M. (1983). Sodium fluoride stimulates $(1,3)-\beta$-D-glucan synthase from Candida albicans. FEMS Microbiol Lett 18, 31-35.

Pesti, M., Campbell, J. M. \& Peberdy, J. F. (1981). Alteration of ergosterol content and chitin synthase activity in Candida albicans. Curr Microbiol 5, 187-190.

Pierce, A. M., Pierce, H. D., Jr, Unrau, A. M. \& Oehlschlager, A. C. (1978). Lipid composition and polyene resistance of Candida albicans mutants. Can J Biochem 56, 135-142.

Quigley, D. R., Hrmova, M. \& Selitrennikoff, C. P. (1988). $\beta-(1-3)$ Glucan synthase of Neurospora crassa: solubilization and partial characterization. Exper Mycol 12, 141-150.

Ram, S., Sullivan, P. A. \& Shepherd, M. G. (1983). The in situ assay of Candida albicans enzymes during yeast and germ-tube formation. $J$ Gen Microbiol 129, 2367-2378.

Ruiz-Herrera, J. (1992). Fungal Cell Wall: Structure, Synthesis, and Assembly, pp. 59-88. Boca Raton: CRC Press.

San-Blas, G. \& San-Blas, F. (1982). Effect of detergents on membrane-associated glucan synthase from Paracoccidioides brasiliensis. J Bacteriol 152, 563-566.

Schmatz, D. M., Romancheck, M. A., Pitarelli, L. A., Schwartz, R. E., Fromtling, R. A., Nollastadt, K. H., Van Middlesworth, F. L., Wilson, K. E. \& Turner, M. J. (1990). Treatment of Pneumocystis carinii pneumonia with 1,3- $\beta$-glucan synthesis inhibitors. Proc Natl Acad Sci US A 87, 5950-5954.

Sentandreu, R., Elorza, M. V. \& Villanueva, J. R. (1975). Synthesis of yeast wall glucan. J Gen Microbiol 90, 13-20.

Shematek, E. M. \& Cabib, E. (1980). Biosynthesis of the yeast cell wall. II Regulation of $\beta$-(1-3) glucan synthetase by ATP and GTP. J Biol Chem 255, 895-902.

Shematek, E. M., Braatz, J. A. \& Cabib, E. (1980). Biosynthesis of the yeast cell wall. I. Preparation and properties of $\beta-(1-3)$ glucan synthetase. J Biol Chem 255, 888-894.

St. Georgiev, V. (1988). Fungal infections and the search for novel antifungal agents. Ann NY Acad Sci 544, 1-3.

Sternweis, P. C. \& Gilman, A. G. (1982). Aluminium: a requirement for activation of the regulatory component of adenylate cyclase by fluoride. Proc Natl Acad Sci US A 79, 4888-4891.

Szaniszlo, P. J., Kang, M. S. \& Cabib, E. (1985). Stimulation of $\beta-(1-$ 3) glucan synthetase of various fungi by nucleoside triphosphates: Generalized regulatory mechanism for cell wall biosynthesis. $J$ Bacteriol 161, 1188-1194.

Taft, C. S., Stark, T. \& Selitrennikoff, C. P. (1988). Cilofungin (LY121019) inhibits Candida albicans $(1,3)-\beta$-glucan synthase activity. Antimicrobial Agents Chemother 32, 1901-1903.

Tang, J. \& Parr, T. R. (1991). W-1 Solubilization and kinetics of inhibition by cilofungin of Candida albicans $(1,3)-\beta$-D-glucan synthase. Antimicrobial Agents Chemotber 35, 99-103.

Received 13 December 1993; revised 14 March 1994; accepted 12 April 1994. 